Article

\title{
Protective Effects of 6,7,4'-Trihydroxyflavanone on Hypoxia-Induced Neurotoxicity by Enhancement of HO-1 through Nrf2 Signaling Pathway
}

\author{
Hyun-Su Lee and Gil-Saeng Jeong * \\ College of Pharmacy, Keimyung University, 1095 Dalgubeol-daero, Daegu 42601, Korea; hyunsu.lee@kmu.ac.kr \\ * Correspondence: gsjeong@kmu.ac.kr; Tel.: +82-53-580-6649
}

Citation: Lee, H.-S.; Jeong, G.-S.

Protective Effects of 6,7, $4^{\prime}$ -

Trihydroxyflavanone on

Hypoxia-Induced Neurotoxicity by Enhancement of HO-1 through Nrf2 Signaling Pathway. Antioxidants 2021, 10, 341. https://doi.org/10.3390/ antiox10030341

Academic Editor: Elzbieta Salinska

Received: 30 December 2020

Accepted: 19 February 2021

Published: 24 February 2021

Publisher's Note: MDPI stays neutral with regard to jurisdictional claims in published maps and institutional affiliations.

Copyright: (c) 2021 by the authors. Licensee MDPI, Basel, Switzerland. This article is an open access article distributed under the terms and conditions of the Creative Commons Attribution (CC BY) license (https:/ / creativecommons.org/licenses/by/ $4.0 /)$.

\begin{abstract}
Since hypoxia-induced neurotoxicity is one of the major causes of neurodegenerative disorders, including the Alzheimer's disease, continuous efforts to find a novel antioxidant from natural products are required for public health. 6,7,4'-trihydroxyflavanone (THF), isolated from Dalbergia odorifera, has been shown to inhibit osteoclast formation and have an antibacterial activity. However, no evidence has reported whether THF has a protective role against hypoxia-induced neurotoxicity. In this study, we found that THF is not cytotoxic, but pre-treatment with THF has a cytoprotective effect on $\mathrm{CoCl}_{2}$-induced hypoxia by restoring the expression of anti-apoptotic proteins in SH-SY5y cells. In addition, pre-treatment with THF suppressed $\mathrm{CoCl}_{2}$-induced hypoxia-related genes including HIF1 $\alpha$, p53, VEGF, and GLUT1 at the mRNA and protein levels. Pre-treatment with THF also attenuated the oxidative stress occurred by $\mathrm{CoCl}_{2}$-induced hypoxia by preserving antioxidant proteins, including SOD and CAT. We revealed that treatment with THF promotes HO-1 expression through Nrf2 nuclear translocation. An inhibitor assay using tin protoporphyrin IX (SnPP) confirmed that the enhancement of HO-1 by pre-treatment with THF protects SH-SY5y cells from $\mathrm{CoCl}_{2}$-induced neurotoxicity under hypoxic conditions. Our results demonstrate the advantageous effects of THF against hypoxia-induced neurotoxicity through the HO-1/Nrf2 signaling pathway and provide a therapeutic insight for neurodegenerative disorders.
\end{abstract}

Keywords: 6,7,4'-trihydroxyflavanone; cobalt chloride; hypoxia; protection; neurotoxicity; nuclear factor erythroid 2-related factor 2 pathway

\section{Introduction}

Since continuous provision of enormous amounts of oxygen to the brain is required for its proper function, the brain is easily affected by the limited oxygen condition called hypoxia. Neuronal cytotoxicity is generally induced under hypoxic condition because insufficient supply of oxygen to the brain enhances the mortality and disability of neurons [1,2]. It has been reported that hypoxia-induced neurotoxicity causes brain damage and leads to neurodegenerative diseases, including Alzheimer's disease, vascular dementia, and Parkinson's disease [3,4].

Hypoxia inducible factor $1 \alpha(\mathrm{HIF} 1 \alpha)$ has been elucidated as the representative transcription factor of hypoxic condition that can be accumulated in cerebral cortex and hippocampus $[5,6]$. Several studies have reported that HIF1 $\alpha$ induces the expression of various genes associated with cell survival, angiogenesis, or glucose uptake, including p53, vascular endothelial growth factor (VEGF), and GLUT1 to overcome hypoxic challenges [7-9]. These altered microenvironments promote oxidative stress by generating reactive oxygen species (ROS) in neuronal cells, leading to neuronal toxicity. Therefore, the importance is gradually elevated to develop a modulator in the neurotoxic condition induced by hypoxia.

Most cells have developed an endogenous self-defense strategy against ROS-induced damage. One of the most widely studied mechanisms is the promotion of heme oxygenase1 (HO-1) expression via the nuclear transcription factor erythroid 2-like factor 2 (Nrf2) 
pathway $[10,11]$. The cytoprotective role of Nrf2 pathway has been reported to significantly reduce the cytotoxicity under hypoxic conditions [12]. Nonetheless, the protective effect of HO-1 via the Nrf2 pathway is important, and little evidence has been reported on whether bioactive molecules isolated from natural products induce the HO-1/Nrf2 pathway to reduce neurotoxicity induced by hypoxia.

6,7,4'-trihydroxyflavanone (THF), isolated from Dalbergia odorifera, is a flavonoid categorized in the flavanone family. D. odorifera has been studied to mainly live in Southern China, including Hainan, Fujian, Guangdong, and Zhejiang [13]. In East Asia, including Korea and China, D. odorifera extract has long been used as a therapeutic agent for rheumatic and epigastric pain, blood stagnation syndrome, ischemia, and swelling [14]. Accumulating evidences demonstrate that THF exhibits effective regulation of osteoclastogenesis by controlling bone resorption and protective role against methamphetamine-induced cytotoxicity on T cells $[15,16]$. In particular, it has been reported that THF effectively suppresses the NF- $\mathrm{KB}$ pathway in two studies to possess anti-osteoclastogenesis and cytoprotective effect against methamphetamine exposure. However, naringenin, one of the flavanone that has a similar structure with THF, has been elucidated to have a radical scavenging activity and protect liver tissue by acting as antioxidant $[17,18]$, no evidence has been reported if THF possesses an antioxidant effect in $\mathrm{CoCl}_{2}$-induced hypoxia condition. In this study, we investigated whether treatment with THF has a cytoprotective role by inducing $\mathrm{HO}-1$ expression through the Nrf2 pathway. In addition, we also explored whether induction of HO- 1 by pre-treatment with THF attenuates hypoxia and oxidative stress to suppress neurotoxicity under hypoxic conditions.

\section{Materials and Methods}

\subsection{Cells}

SH-SY5y neuroblastoma cells were obtained from the Korean Cell Line Bank (KCLB No. 22266, Seoul, Republic of Korea). The cells were identified by STR profiling including D7S820, D5S818, D13S317, FGA, vWA, TPOX, and TH01 by distributor. The cells were grown in DMEM medium (Welgene, Gyeongsan-si, Republic of Korea) supplemented with $10 \%$ fetal bovine serum (FBS), penicillin G (100 units $/ \mathrm{mL})$, L-glutamine $(2 \mathrm{mM})$, and streptomycin $(100 \mu \mathrm{g} / \mathrm{mL})$ at $37^{\circ} \mathrm{C}$ in a humidified incubator containing $5 \% \mathrm{CO}_{2}$. Cells were maintained within passage \#14 prior to any experiments.

\subsection{Isolation of 6,7,4'-Tryhydroxyflavanone from Dalbergia Odorifera}

THF $\left(\mathrm{C}_{15} \mathrm{H}_{12} \mathrm{O}_{5}\right.$, Figure 1) was isolated from D. odorifera as previously reported [15]. Briefly, D. odorifera was purchased from the Herbal Medicine Cooperative Association of Jeonbuk Province, Korea. Dried D. odorifera $(20 \mathrm{~kg})$ was extracted three times with 100\% $\mathrm{EtOH}$. The filtered $\mathrm{EtOH}$ extract $\left(2.416 \mathrm{~kg}\right.$ ) was concentrated and partitioned with $\mathrm{CH}_{2} \mathrm{Cl}_{2}$. The $\mathrm{CH}_{2} \mathrm{Cl}_{2}$-soluble fraction (200 g) was subjected to chromatography on a silica gel column with n-hexane-EtOAc (1:0 to 0:1) to obtain five fractions (Fr. 1 to Fr. 5). Among them, Fr. 3 $(120 \mathrm{~g})$ was separated on a Sephadex LH-20 column with a mixture of solvents $\left(\mathrm{MeOH}: \mathrm{H}_{2} \mathrm{O}\right.$ = 9:1) and four fractions were obtained (Fr. 3-1 to Fr. 3-4). Of the four fractions, Fr. 3-3 $(30 \mathrm{~g})$ was further purified on a Sephadex LH-20 column with a mixture of solvents (EtOAc: $\mathrm{MeOH}=4: 1$ ) and loaded on a silica gel column with a gradient mixture of solvents from $100 \%$ n-hexane to $100 \%$ EtOAc to obtain fifteen fractions (Fr. 3-3-1 to Fr. 3-3-15). Among them, Fr. 3-3-4 (120 mg) was characterized as THF by comparing the newly obtained ${ }^{1} \mathrm{H}$ and ${ }^{13} \mathrm{C}$ nuclear magnetic resonance (NMR, JEOL JNM-ECA 500) spectral data with a previous report [19]. The purity was determined to be $98.8 \%$ based on NMR. 


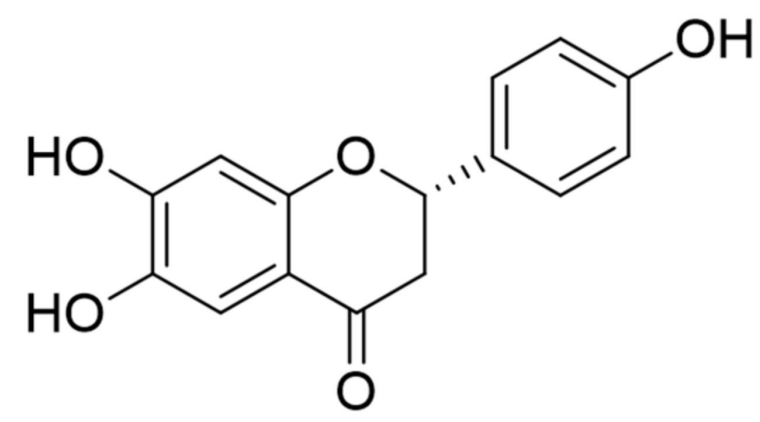

Figure 1. The chemical structure of 6,7, $4^{\prime}$-trihydroxyflavanone (THF).

\subsection{Reagents and Antibodies}

MTT powder (1-(4,5-Dimethylthiazol-2-yl)-3,5-diphenylformazan), RIPA buffer, TRIZOL reagent, $\mathrm{CoCl}_{2}$, DCF-DA, and Protoporphyrin IX (SnPP) were purchased from Sigma Chemical Co. (St. Louis, MO, USA). AnnexinV/PI apoptosis assay kit was obtained from BD Biosciences (San Diego, CA, USA). Antibodies against Caspase3, Caspase7, Caspase8, Caspase9, HIF1 $\alpha$, p53, VEGF, GLUT1, SOD, CAT, HO-1, and LaminB were purchased from Cell Signaling Technology (Danvers, MA, USA). Anti-Bcl-2, anti- $\beta$-actin, and anti-Nrf2 antibodies were obtained from Santa Cruz Biotechnology (Dallas, TX, USA). The RT PreMix kit was purchased from Enzynomics (Daejeon, Korea). SYBR Premix Ex Taq was obtained from Takara (Shiga, Japan). Nuclear and Cytoplasmic Extraction Reagents Kit (NE-PER) and ECL Western blot detection reagents were purchased from Thermo Fisher Scientific (Waltham, MA, USA).

\subsection{MTT Assay}

Seeded SH-SY5y cells $\left(1 \times 10^{4}\right.$ /well, 96-well plate) were treated with the indicated concentration of THF $(0-40 \mu \mathrm{M})$ for $24 \mathrm{~h}$. The supernatants were discarded and $500 \mu \mathrm{g} / \mathrm{mL}$ of MTT was incubated with the cells for $1 \mathrm{~h}$. Supernatants were removed and generated formazan crystals were dissolved in $170 \mu \mathrm{L}$ of DMSO. Plate was read to gain the absorbance at $540 \mathrm{~nm}$ and cell viability was determined by comparing with absorbance of control cells (\% of control).

\subsection{Determination of Dead Cell Population by AnnexinV Staining}

Seeded SH-SY5y cells $\left(1 \times 10^{4}\right.$ / well, 96-well plate) were stained with $1 \times$ AnnexinV staining reagent for IncuCyte for $30 \mathrm{~min}$. Then cells were treated with the indicated concentration of THF $(0-40 \mu \mathrm{M})$ for $24 \mathrm{~h}$ or pre-treated with the indicated concentration of THF $(0-40 \mu \mathrm{M})$ for $6 \mathrm{~h}$ and incubated with $0.5 \mathrm{mM} \mathrm{CoCl}_{2}$ for $24 \mathrm{~h}$. After incubation, the intensity of AnnexinV was assessed by IncuCyte imaging system and DIC images were obtained with AnnexnV fluorescence (green). Integrated intensity of AnnexinV was determined by comparing with control cells (\% of control).

\subsection{Western Blot Analysis}

SH-SY5y cells cultured in the indicated conditions were harvested for lysis in RIPA buffer with $1 \times$ phosphatase inhibitor at $4{ }^{\circ} \mathrm{C}$ for $20 \mathrm{~min}$. Lysates were centrifuged at $13,500 \mathrm{rpm}$ at $4{ }^{\circ} \mathrm{C}$ for $20 \mathrm{~min}$ and 30 to $50 \mu \mathrm{g}$ of the lysate was separated on $8-12 \%$ sodium dodecyl sulfate polyacrylamide gel electrophoresis (SDS-PAGE) gels. Proteins were transferred onto PVDF membranes, which were then blocked with 5\% skimmed milk for $1 \mathrm{~h}$. After blocking, membranes were incubated with the respective primary antibodies in 3\% skim milk overnight (1:1000 ratio). Excess primary antibodies were removed by washing the membrane four times with TBS-T and incubated with $0.1 \mu \mathrm{g} / \mathrm{mL}$ peroxidaselabeled secondary antibodies (against rabbit or mouse) for $1 \mathrm{~h}$. After four washes with TBS-T, bands were detected with ECL Western blot detection reagents with an ImageQuant LAS 4000 (GE Healthcare, Chicago, IL, USA). 


\subsection{Apoptosis Assay}

Apoptotic neurotoxicity of SH-SY5y cells was assessed by a double staining experiment using AnnexinV and PI. After incubation of SH-SY5y neuroblastoma cells treated with the indicated conditions, cells were suspended in $1 \times$ trypsin-ethylenediaminetetraacetic acid (EDTA) buffer. After washing with cold PBS, cells were resuspended in $100 \mu \mathrm{L}$ of $1 \times$ binding buffer containing AnnexinV $(20 \mu \mathrm{g} / \mathrm{mL})$ and PI $(1 \mu \mathrm{g} / \mathrm{mL})$ for $15 \mathrm{~min}$ at RT. Stained cells were acquired on a BD FACSVerse (BD Biosciences, San Diego, CA, USA), and the population of Annexin $V^{+}$cells or AnnexinV $V^{+} / \mathrm{PI}^{+}$cells was presented in the bar graph with plots.

\subsection{RT-PCR and Realtime Quantitative RT-PCR}

Total RNA was isolated from cells treated with the indicated conditions using TRIZOL reagent and reverse transcription of the RNA to cDNA was performed. Primers used for each gene were as follows (forward and reverse primers, respectively). human HIF1a, $5^{\prime}$-ATC CAT GTG ACC ATG AGG AAA TG- ${ }^{\prime}$ and $5^{\prime}$-TCG GCT AGT TAG GGT ACA CTT C-3' (accession number: NM_181054); human $p 53,5^{\prime}$-CCT CAG CAT CTT ATC CGA GTG G-3' and $5^{\prime}$-TGG ATG GTG GTA CAG TCA GAG C-3' (accession number: NM_000546), human VEGF, 5' -ACC AAG GCC AGC ACA TAG G-3' and 5'-ACG CTC CAG GAC TTA TAC CG-3' (accession number: NM_001171623), human GLUT1, 5' CCA ACT GGA C- $3^{\prime}$ and $5^{\prime}$-CAG AAC CAG GAG CAC AGT GAA G-3' (accession number: NM_006516), human SOD, $5^{\prime}$-CTC ACT CTC AGG AGA CCA TTG C- $3^{\prime}$ and $5^{\prime}$-CCA CAA GCC AAA CGA CTT CCA G-3' (accession number: NM_000454), human CAT, 5'-CTT GGA ACA TTG TAC CCG CT- $3^{\prime}$ and $5^{\prime}$-GTC CAG AAG AGC CTG AAT GC-3' (accession number: NM_214301), human GAPDH, 5'-CGG AGT CAA CGG ATT TGG TCG TAT-3' and 5'-AGC CTT CTC CAT GGT GGT GAA GAC-3' (accession number: NM_001256799). For quantitative PCR analysis, amplification was performed in a DNA Engine Opticon 1 continuous fluorescence detection system (MJ Research, Waltham, MA, USA) using SYBR Premix Ex Taq. The total reaction volume was $10 \mu \mathrm{L}$ containing $0.1 \mu \mathrm{g}$ of cDNA and each PCR reaction was performed using the following conditions: $95^{\circ} \mathrm{C}$ for $30 \mathrm{~s}, 60^{\circ} \mathrm{C}$ for $30 \mathrm{~s}$, and plate read for 40 cycles followed by $7 \mathrm{~min}$ of extension at $72{ }^{\circ} \mathrm{C}$. Melting curve analysis was performed to characterize the dsDNA product by slowly raising the temperature $\left(0.15^{\circ} \mathrm{C} / \mathrm{s}\right)$ from $60^{\circ} \mathrm{C}$ to $95^{\circ} \mathrm{C}$ with fluorescence data collected at $0.15^{\circ} \mathrm{C}$ intervals. mRNA levels of genes were normalized with the mRNA levels of GAPDH and were presented as "\% of maximum". The "\% of maximum" was calculated using the following equation: $\%$ of maximum $=2^{-\Delta \Delta C T} \times 100$, where $\Delta \Delta C T=($ CTtarget $-\mathrm{CTgapdh})$ at maximum-(CTtarget-CTgapdh).

\subsection{Reactive Oxygen Species (ROS) Measurement}

SH-SY5y cells incubated with the indicated conditions were stained with $2 \mu \mathrm{M}$ DCFDA for $20 \mathrm{~min}$ in the dark. Generated fluorescence was assessed using the IncuCyte imaging system. The intensity of $2^{\prime}, 7^{\prime}$-dichlorofluorescin Diacetate (DCF-DA) was obtained from IncuCyte software and the \% of maximum was calculated and presented in bar graph.

\subsection{Detection of Nrf2 Nuclear Translocation}

To detect Nrf2 nuclear translocation in SH-SY5y cells after treatment with THF, cells were incubated with the indicated concentration of THF for $1 \mathrm{~h}$ and collected. Nuclear extracts and cytosolic extracts were separated from the whole lysate using the NE-PER Kit. For SDS-PAGE, $20 \mu \mathrm{g}$ of nuclear extract and $50 \mu \mathrm{g}$ of cytosolic extract was loaded in $8 \%$ SDS gel. Nuclear extracts and cytosolic extracts were normalized with the level of LaminB and $\beta$-actin, respectively.

\subsection{Statistics}

Mean values \pm SEM were evaluated from the data obtained from three independent experiments performed on separate days and presented as bar graphs. One-way ANOVA 
was used to determine significance ( $p$ value). ${ }^{*}$ indicates differences from the mock-treated group or between two indicated groups considered significant at $p<0.05$.

\section{Results}

\subsection{THF Does Not Induce Cell Death and Apoptosis in SH-SY5y Cells}

Since it has been previously reported that THF is not cytotoxic to RAW 264.7 cells [15], we first confirmed whether THF shows cytotoxicity in SH-SY5y neuronal cells. Figure 2A shows that treatment with up to $40 \mu \mathrm{M}$ of THF does not induce cell death. The measurement of intensity of AnnexinV also exhibited that THF does not affect cell death in SH-SY5y cells (Figure 2B). The changes of cell number was not shown in cells incubated with THF up to $40 \mu \mathrm{M}$ (Figure 2C). To investigate whether THF is associated with apoptosis in SH-SY5y cells, the changes in expression of apoptosis-related proteins after THF treatment were determined. As shown in Figure 2D, the expression of Bcl2 and caspase family, which are highly involved in apoptosis, were not altered by THF treatment. The results from the apoptosis assay also demonstrated that SH-SY5y cells treated with up to $40 \mu \mathrm{M}$ THF did not undergo apoptotic pathway (Figure 2E). These data suggest that THF does not induce cell death and apoptosis in SH-SY5y cells.
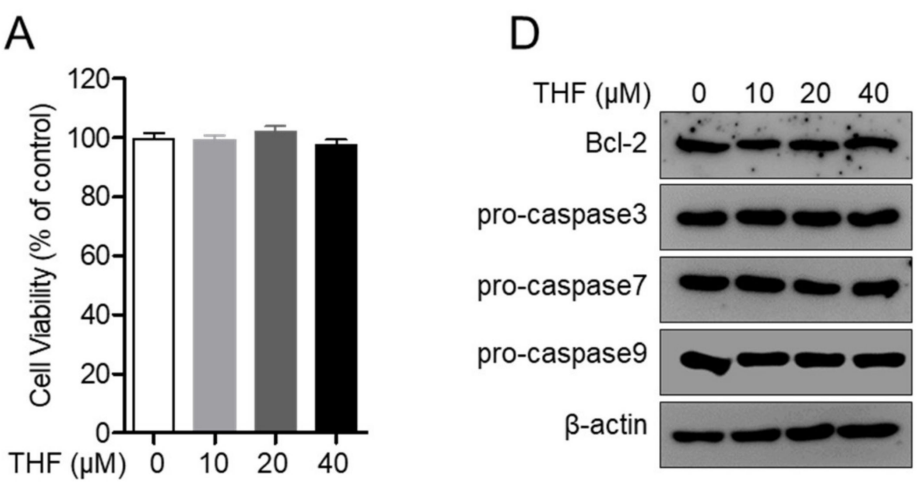

C

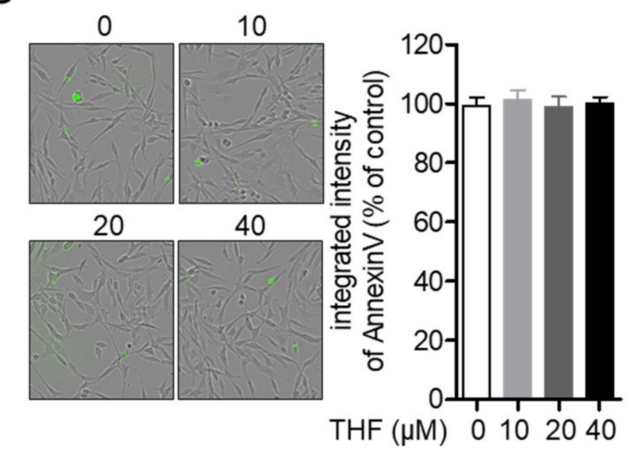

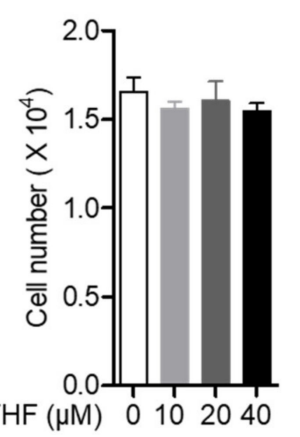

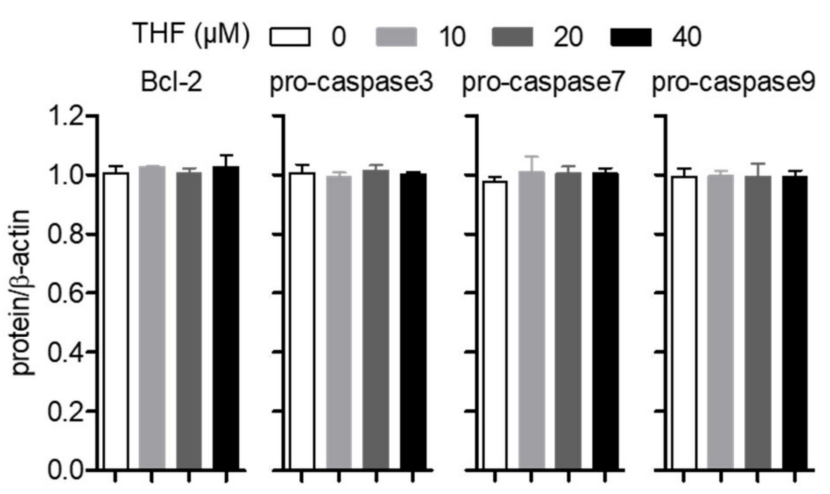

$\mathrm{E}$

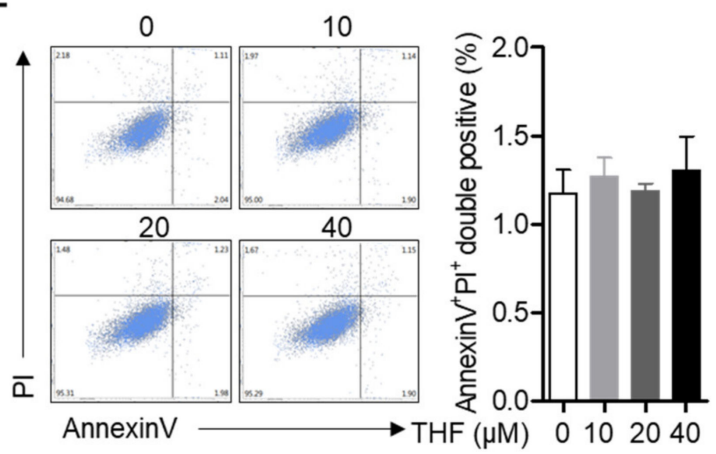

Figure 2. THF does not induce cell death and apoptosis in SH-SY5y cells. (A) SH-SY5y cells $\left(1 \times 10^{4} /\right.$ well, 96 -well plate) were seeded and treated with the indicated concentration ( 0 to $40 \mu \mathrm{M})$ of THF for $24 \mathrm{~h}$. Cell viability was assessed by MTT assay. (B,C) SH-SY5y cells $\left(1 \times 10^{4} /\right.$ well, 96-well plate) were stained with $1 \mathrm{X}$ AnnexinV staining reagent and treated with the indicated concentration $(0$ to $40 \mu \mathrm{M})$ of THF for $24 \mathrm{~h}$. The intensity of AnnexinV was assessed by IncuCyte imaging system (B) and cell number was counted after trypan blue staining (C). (D) SH-SY5y cells $\left(1 \times 10^{5} /\right.$ well, 6-well plate) were treated with the indicated concentration $(0$ to $40 \mu \mathrm{M})$ of THF for $24 \mathrm{~h}$ and collected for Western blot analysis. Indicated proteins were detected and normalized with the level of $\beta$-actin. (E) Apoptosis assay was performed with SH-SY5y cells treated with the indicated concentration $(0$ to $40 \mu \mathrm{M})$ of THF for $24 \mathrm{~h}$. The mean value of three experiments \pm SEM is presented. 


\subsection{THF Protects SH-SY5y Cells from $\mathrm{CoCl}_{2}$-Induced Cytotoxicity in Hypoxic Condition}

It has been widely established that treatment with cobalt chloride $\left(\mathrm{CoCl}_{2}\right)$ induces hypoxia in neuronal cells [20]. To understand whether $\mathrm{CoCl}_{2}$ leads to neurotoxicity in SH-SY5y cells, MTT assay was performed. Figure 3A showed that cellular viability was reduced in dose-dependent manner. To evaluate whether pre-treatment with THF has a protective effect on the neuronal cytotoxicity induced by treatment with $\mathrm{CoCl}_{2}$, cell viability was assessed by MTT assay. Figure 3B shows that the viability of SH-SY5y cells pre-treated with THF was significantly restored in a dose-dependent manner compared to cells pre-treated with mock. The intensity of AnnexinV was also partially inhibited by pretreatment with THF in $\mathrm{CoCl}_{2}$-induced hypoxia (Figure 3C). Cell number was also confirmed that pre-treatment with THF preserves cell viability in $\mathrm{CoCl}_{2}$-induced hypoxia condition (Figure 3D). To confirm if THF pre-treatment protects SH-SY5y cells from $\mathrm{CoCl}_{2}$-induced apoptosis, the population of AnnexinV- and PI-positive cells was determined by flow cytometry. As shown in Figure 3E, exposure to $\mathrm{CoCl}_{2}$ led to the apoptotic pathway in $\mathrm{SH}-$ SY5y cells, but THF pre-treatment partially restored the $\mathrm{CoCl}_{2}$-induced apoptosis in a dosedependent manner. These data demonstrate that $\mathrm{CoCl}_{2}$ treatment induces neurotoxicity in SH-SY5y cells, but THF pre-treatment effectively preserves cellular death and apoptosis in a dose-dependent manner.

A

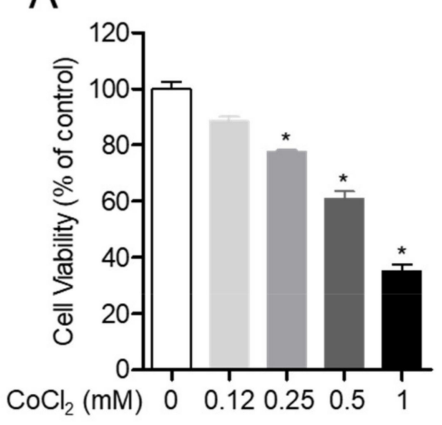

C

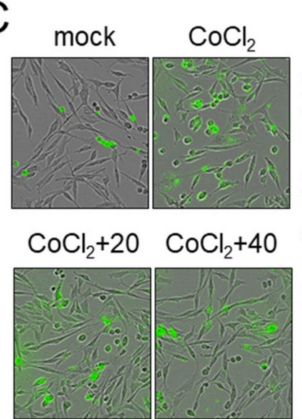

B

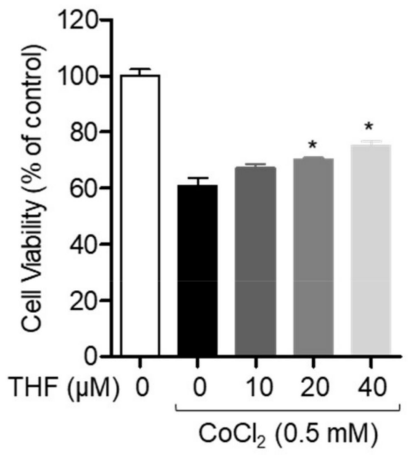

$\mathrm{E}$

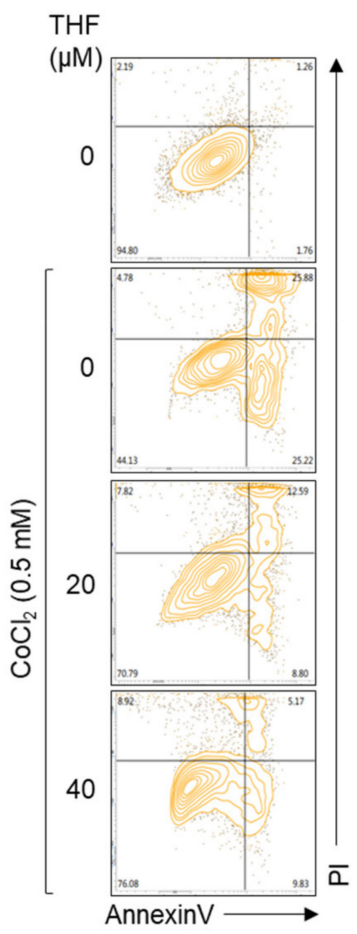

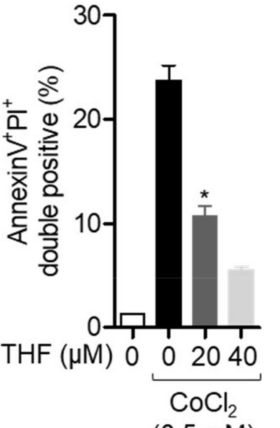

$\mathrm{D}$

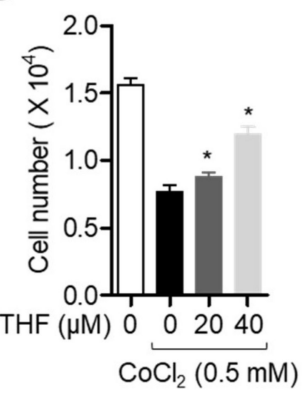

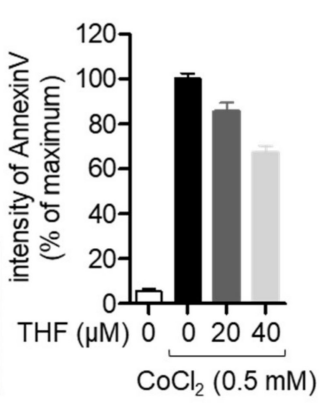

Figure 3. THF protects $\mathrm{SH}-\mathrm{SY} 5 \mathrm{y}$ cells from $\mathrm{CoCl}_{2}$-induced cytotoxicity in hypoxic condition.

(A) SH-SY5y cells $\left(1 \times 10^{4}\right.$ /well, 96-well plate) were treated with the indicated concentration (0 to $\left.1 \mathrm{mM}\right)$ of $\mathrm{CoCl}_{2}$ for $24 \mathrm{~h}$. Cell viability was assessed by MTT assay. (B) SH-SY5y cells $\left(1 \times 10^{4} /\right.$ well, 96 -well plate $)$ were pre-treated with the indicated concentration ( 0 to $40 \mu \mathrm{M})$ of THF for $6 \mathrm{~h}$ and treated with $0.5 \mathrm{mM} \mathrm{CoCl}_{2}$ for $24 \mathrm{~h}$. Cell viability was assessed by MTT assay. (C,D) SH-SY5y cells $\left(1 \times 10^{4} /\right.$ well, 96-well plate) were stained with $1 \mathrm{X}$ AnnexinV staining reagent and pre-treated with the indicated concentration ( 0 to $40 \mu \mathrm{M}$ ) of THF for $6 \mathrm{~h}$. After pre-treatment, cells were incubated with $0.5 \mathrm{mM} \mathrm{CoCl}_{2}$ for $24 \mathrm{~h}$. The intensity of AnnexinV was assessed by IncuCyte imaging system (C) and cell number was counted after trypan blue staining (D). (E) Apoptosis assay was performed with SH-SY5y cells pre-treated with the indicated concentration (0 to $40 \mu \mathrm{M}$ ) of THF for $6 \mathrm{~h}$ and treated with $0.5 \mathrm{mM} \mathrm{CoCl}_{2}$ for $24 \mathrm{~h}$. The mean value of three experiments $\pm \mathrm{SEM}$ is presented. * $p<0.05$ between mock-treated cells. 


\subsection{THF Blocks the Cleavage of Caspase Family in $\mathrm{CoCl}_{2}$-Induced Hypoxia Condition}

It has been evaluated that the fate of cells undergoing apoptotic pathway is tightly controlled by the expression of apoptosis-related proteins [21]. To elucidate the changes in the expression of apoptosis-related proteins after $\mathrm{CoCl}_{2}$ treatment of $\mathrm{SH}-\mathrm{SY} 5 \mathrm{y}$ cells, the expression of $\mathrm{Bcl} 2$ and caspase family was determined by Western blot analysis. Figure $4 \mathrm{~A}$ shows that $\mathrm{CoCl}_{2}$ treatment downregulates the expression of $\mathrm{Bcl} 2$ and cleavage of caspase 3 and 7 in SH-SY5y cells in a dose-dependent manner. To validate whether THF pre-treatment blocks reduction of the apoptosis-related proteins in $\mathrm{CoCl}_{2}$-induced hypoxic condition, Western blot analysis was performed. As shown in Figure 4B, THF pre-treatment partially restored the suppressed expression of $\mathrm{Bcl} 2$ and led to cleavage of caspase 3 and caspase7 by $\mathrm{CoCl}_{2}$ treatment. These data suggest that THF pre-treatment preserves the expression of anti-apoptotic proteins but suppresses the active caspase family in $\mathrm{CoCl}_{2}$-induced hypoxic condition.
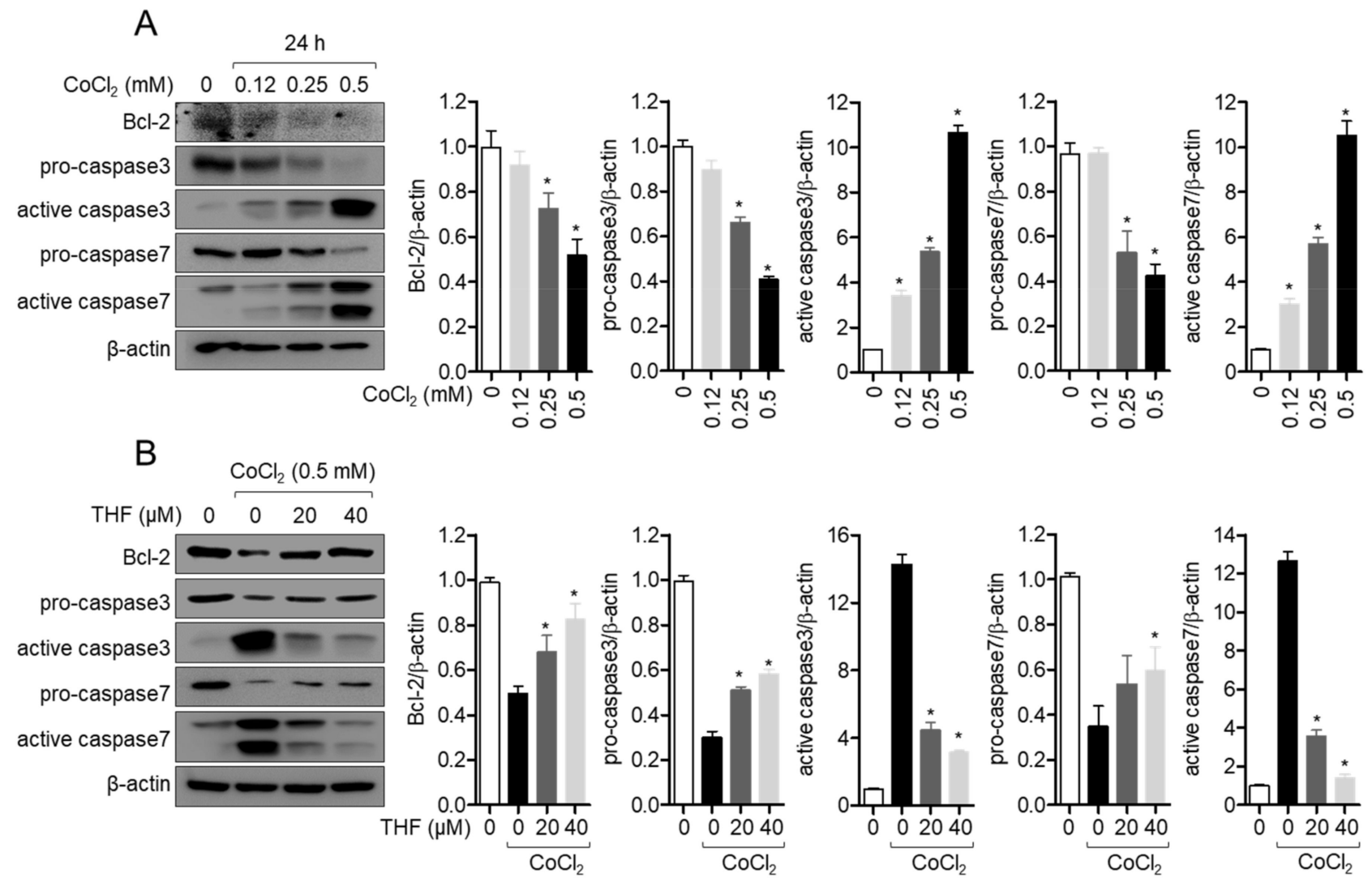

Figure 4. THF blocks the cleavage of caspase family in CoCl2-induced hypoxia condition. (A) SH-SY5y cells $\left(1 \times 10^{5} /\right.$ well, 6-well plate) were treated with the indicated concentration ( 0 to $0.5 \mathrm{mM}$ ) of $\mathrm{CoCl}_{2}$ for $24 \mathrm{~h}$ and collected for Western blot analysis. Indicated proteins were detected and normalized with the level of $\beta$-actin. (B) SH-SY5y cells $\left(1 \times 10^{5} /\right.$ well, 6 -well plate) were pre-treated with the indicated concentration $(0$ to $40 \mu \mathrm{M})$ of THF for $6 \mathrm{~h}$ and treated with $0.5 \mathrm{mM} \mathrm{CoCl}_{2}$ for $24 \mathrm{~h}$. Cells were collected for Western blot analysis and indicated proteins were detected. The mean value of three experiments \pm SEM is presented. ${ }^{*} p<0.05$ between mock-treated cells (A) or $\mathrm{CoCl}_{2}$-treated cells (B).

\subsection{THF Inhibits $\mathrm{CoCl}_{2}$-Induced Hypoxia-Related Genes in SH-SY5y Cells}

To investigate the underlying mechanism of how THF pre-treatment protects the cells from neurotoxicity induced by $\mathrm{CoCl}_{2}$ treatment in $\mathrm{SH}-\mathrm{SY} 5 \mathrm{y}$ cells, we first tested whether THF pre-treatment blocks hypoxia induced by $\mathrm{CoCl}_{2}$ treatment. As shown in Figure $5 \mathrm{~A}, \mathrm{CoCl}_{2}$ exposure induced the mRNA level of HIF1a, a marker of hypoxia, in a dose-dependent manner. Under hypoxic condition, we found that THF pre-treatment significantly inhibited the induction of HIF1a by treatment with $0.5 \mathrm{mM} \mathrm{CoCl}_{2}$ (Figure $5 \mathrm{~B}$ ). 
We also checked if THF pre-treatment reduced the mRNA levels of hypoxia-related genes, including $p 53, V E G F$, and GLUT1. Quantitative RT-PCR results showed that THF pretreatment significantly suppressed the induction of $p 53, V E G F$, and GLUT1 expression (Figure 5B). The regulatory effects of THF pre-treatment on the induction of hypoxiarelated genes were also confirmed by Western blot at the protein level (Figure 5C). These results clearly demonstrate that THF pre-treatment attenuates the $\mathrm{CoCl}_{2}$-induced hypoxic condition in SH-SY5y cells.

A

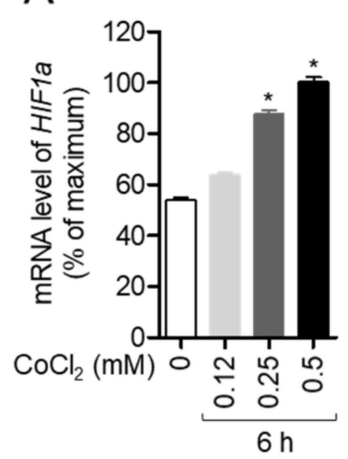

B

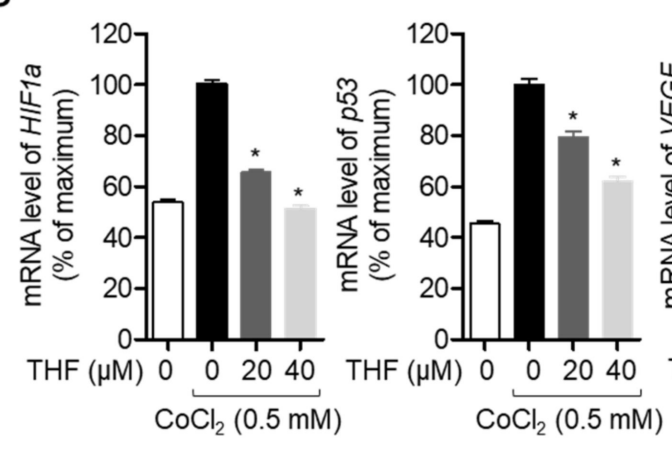

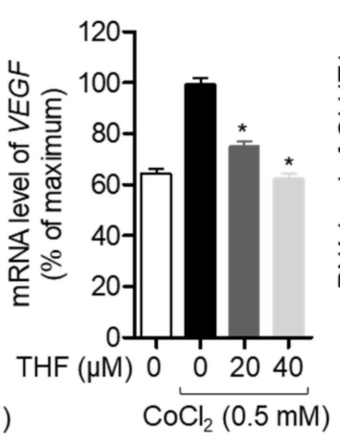

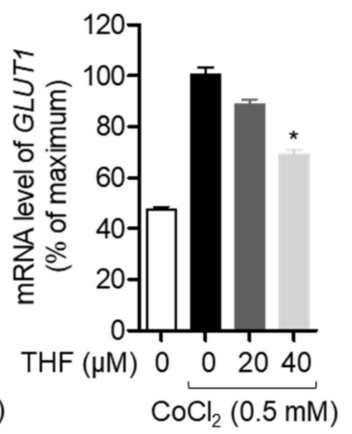

C
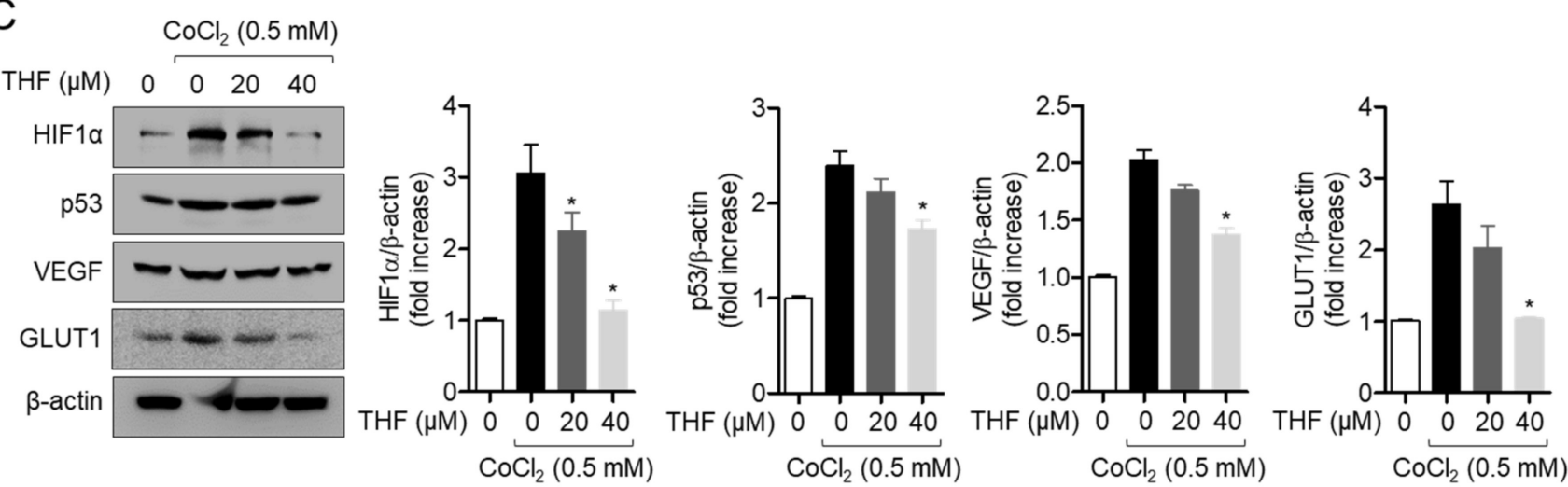

Figure 5. THF inhibits $\mathrm{CoCl}_{2}$-induced hypoxia-related genes in SH-SY5y cells. (A) SH-SY5y cells $\left(1 \times 10^{5} /\right.$ well, 6-well plate) were treated with the indicated concentration $(0$ to $0.5 \mathrm{mM})$ of $\mathrm{CoCl}_{2}$ for $6 \mathrm{~h}$ and collected for the real-time PCR analysis. The mRNA level of HIF1a was measured and normalized with the level of GAPDH. (B) SH-SY5y cells $\left(1 \times 10^{5} /\right.$ well, 6-well plate) were pre-treated with the indicated concentration $(0$ to $40 \mu \mathrm{M})$ of THF for $6 \mathrm{~h}$ and treated with $0.5 \mathrm{mM} \mathrm{CoCl}_{2}$ for $6 \mathrm{~h}$. The mRNA level of the indicated genes were measured and normalized with the level of GAPDH. (C) SH-SY5y cells $\left(1 \times 10^{5} /\right.$ well, 6-well plate) were pre-treated with the indicated concentration $(0$ to $40 \mu \mathrm{M})$ of THF for $6 \mathrm{~h}$ and treated with $0.5 \mathrm{mM} \mathrm{CoCl}^{2}$ for $24 \mathrm{~h}$. Cells were collected for Western blot analysis and indicated proteins were detected. The mean value of three experiments \pm SEM is presented. ${ }^{*} p<0.05$ between mock-treated cells $(\mathbf{A})$ or $\mathrm{CoCl}_{2}$-treated cells $(\mathbf{B}, \mathbf{C})$.

\subsection{THF Attenuates the $\mathrm{CoCl}_{2}$-Induced Oxidative Stress in SH-SY5y Cells}

One of the well-defined cytotoxic mechanisms of hypoxia is the induction of oxidative stress [22]. To explore whether THF pre-treatment is associated with the inhibition of $\mathrm{CoCl}_{2}$-induced oxidative stress, we assessed the ROS generation in THF pre-treated and $\mathrm{CoCl}_{2}$-exposed SH-SY5y cells. Figure $6 \mathrm{~A}$ revealed that enhanced $\mathrm{ROS}$ generation by $\mathrm{CoCl}_{2}$ exposure was significantly suppressed by THF pre-treatment in a dose-dependent manner. Since oxidative stress, including ROS generation by $\mathrm{CoCl}_{2}$, is highly involved in the reduced expression of SOD and CAT, which are antioxidant proteins, we also determined if THF pre-treatment preserves them in $\mathrm{CoCl}_{2}$-induced hypoxia. Quantitative RT-PCR analysis showed that the mRNA levels of SOD and CAT in $\mathrm{CoCl}_{2}$-exposed SH-SY5y cells were downregulated, which was restored by THF pre-treatment (Figure 6B). It was also 
confirmed on the protein level by Western blot analysis that the expressions of SOD and CAT are preserved by THF pre-treatment (Figure 6C). These results suggest that THF pre-treatment mitigates the $\mathrm{CoCl}_{2}$-induced oxidative stress by restoring the expression of antioxidant proteins.

A
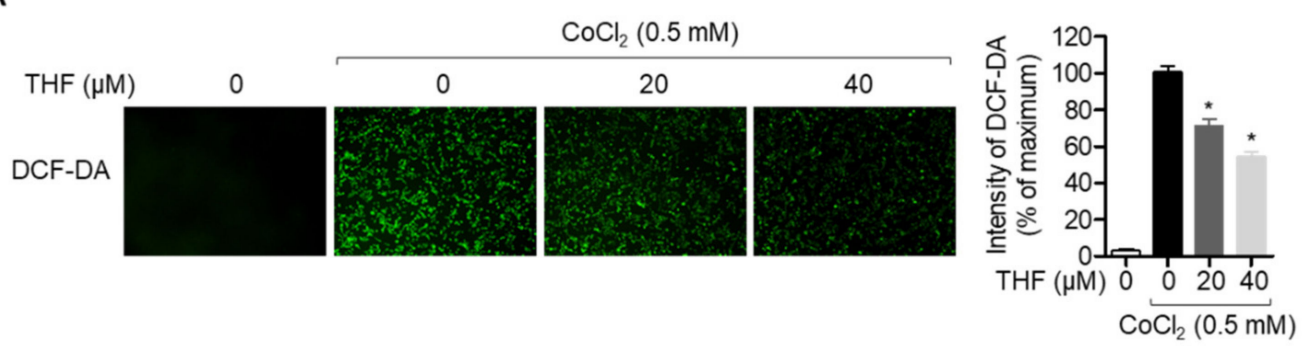

B
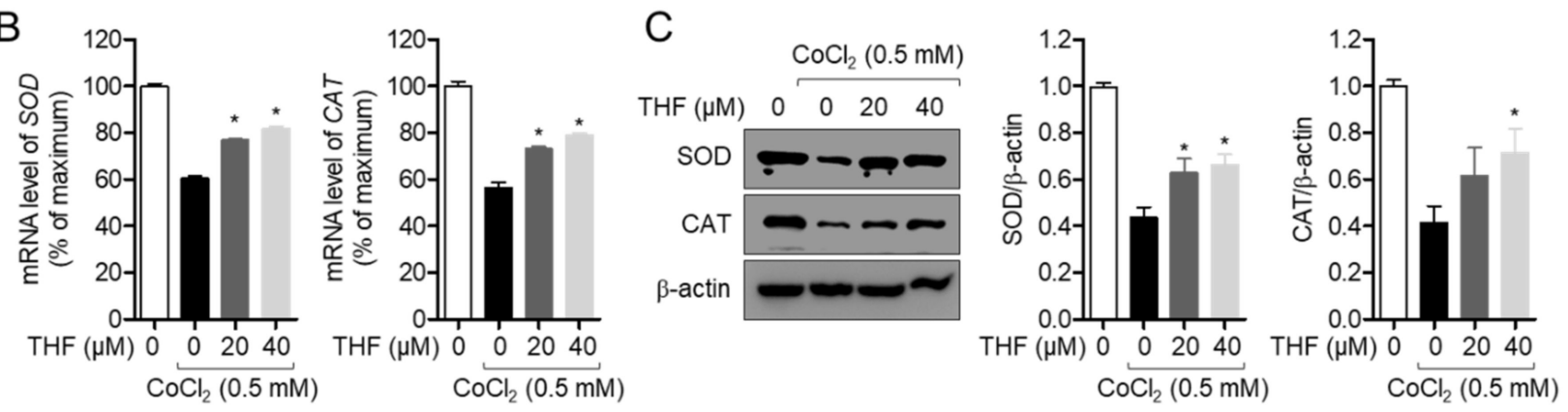

Figure 6. THF attenuates the $\mathrm{CoCl}_{2}$-induced oxidative stress in SH-SY5y cells. (A) SH-SY5y cells $\left(1 \times 10^{4} /\right.$ well, 96 -well plate) were pre-treated with the indicated concentration $(0$ to $40 \mu \mathrm{M})$ of THF for $6 \mathrm{~h}$ and treated with $0.5 \mathrm{mM} \mathrm{CoCl}_{2}$ for $24 \mathrm{~h}$. After incubation with $2 \mu \mathrm{M}$ of DCF-DA for $20 \mathrm{~min}$ in dark, generated ROS were detected by IncuCyte imaging system. (B) SH-SY5y cells $\left(1 \times 10^{5} /\right.$ well, 6 -well plate $)$ were pre-treated with the indicated concentration $(0$ to $40 \mu \mathrm{M})$ of THF for $6 \mathrm{~h}$ and treated with $0.5 \mathrm{mM} \mathrm{CoCl}_{2}$ for $6 \mathrm{~h}$. The mRNA level of the indicated genes were measured and normalized with the level of GAPDH. (C) SH-SY5y cells $\left(1 \times 10^{5} /\right.$ well, 6 -well plate) were pre-treated with the indicated concentration $(0$ to $40 \mu \mathrm{M}$ ) of THF for $6 \mathrm{~h}$ and treated with $0.5 \mathrm{mM} \mathrm{CoCl}_{2}$ for $24 \mathrm{~h}$. Cells were collected for Western blot analysis and indicated proteins were detected. The mean value of three experiments \pm SEM is presented. ${ }^{*} p<0.05$ between $\mathrm{CoCl}_{2}$-treated cells.

\subsection{THF Promotes HO-1 Expression by Leading Nrf2 Translocation in SH-SY5y Cells}

HO-1 has been widely reported as an important product of the antioxidant signaling pathway [23]. To evaluate whether THF treatment is associated with HO-1 induction, we detected the expression of HO-1 in THF-treated SH-SY5y cells in a dose-dependent manner. Figure 7A clearly demonstrates that the expression of HO-1 is induced by THF treatment. The time-dependent experiment showed that the expression of $\mathrm{HO}-1$ was inducible in cells treated with $40 \mu \mathrm{M}$ THF for $6 \mathrm{~h}$ (Figure 7B). Since the Nrf2 pathway is known to be a major signaling pathway for the induction of $\mathrm{HO}-1$, we checked whether treatment with THF leads to the nuclear translocation of Nrf2 into the nucleus in SH-SY5y cells. Figure 7C shows that Nrf2 is translocated into the nucleus by a dose-dependent THF treatment in SH-SY5y cells. Besides, we performed the Western blot assay to explore whether both $\mathrm{CoCl}_{2}$ and THF affect to Nrf2 nuclear translocation and HO-1 expression. As shown in the Figure 7D, HO-1 expression is induced by exposure to $\mathrm{CoCl}_{2}$ but pre-treatment with THF promotes more HO-1 expression compared to $\mathrm{CoCl}_{2}$ exposure only. We also found that exposure to $\mathrm{CoCl}_{2}$ induces the $\mathrm{Nrf} 2$ nuclear translocation but pre-treatment with THF boosts it in SH-SY5y cells (Figure 7E). These data suggest that THF treatment enhances the expression of HO-1 through Nrf2 nuclear translocation and exposure to $\mathrm{CoCl}_{2}$ stimulates the defense mechanism inside cells but pre-treatment with THF improves defense pathway against toxicity including $\mathrm{CoCl}_{2}$ in $\mathrm{SH}-\mathrm{SY} 5 \mathrm{y}$ cells. 

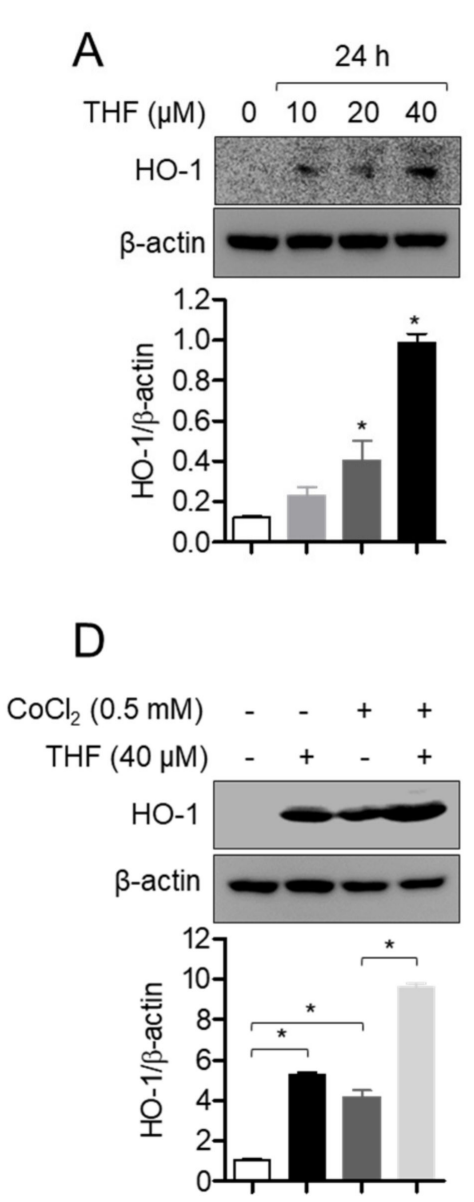
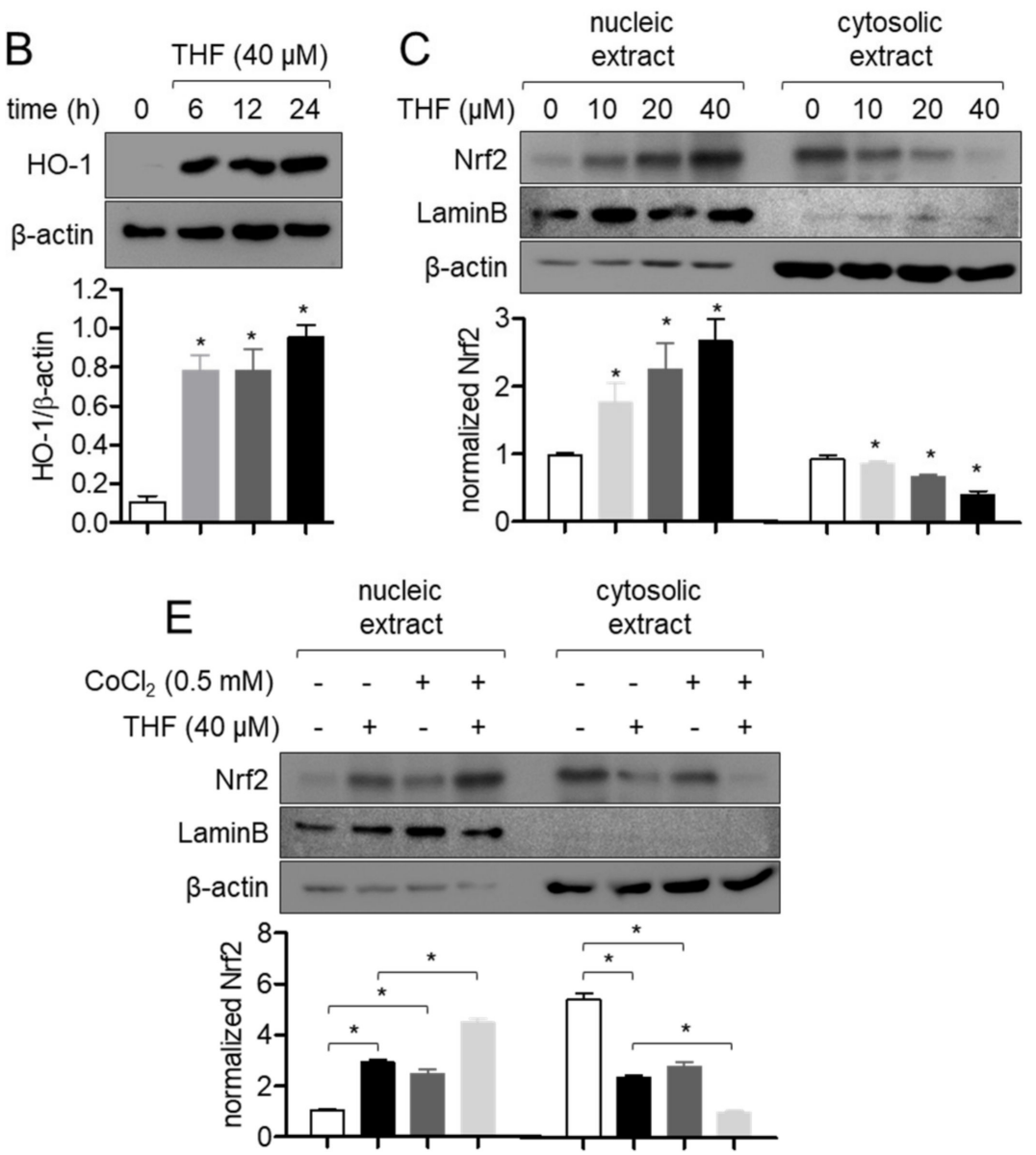

Figure 7. THF promotes HO-1 expression by leading Nrf2 translocation in SH-SY5y cells. (A,B) SH-SY5y cells $\left(1 \times 10^{5} /\right.$ well, 6-well plate) were treated with the indicated concentration $(0$ to $40 \mu \mathrm{M})$ of THF for the indicated time (0 to $24 \mathrm{~h})$ and collected for Western blot analysis. The level of HO-1 was detected and normalized with the level of $\beta$-actin. (C) SH-SY5y cells $\left(1 \times 10^{5}\right.$ /well, 6-well plate) were treated with the indicated concentration $(0$ to $40 \mu \mathrm{M})$ of THF for $1 \mathrm{~h}$ and collected for Western blot analysis. Nucleic extract was separated from whole lysate by using NE-PER kit. The expression of Nrf2 was detected from nucleic extract and cytosolic extract. (D) SH-SY5y cells $\left(1 \times 10^{5} /\right.$ well, 6-well plate) were pre-treated with $40 \mu \mathrm{M}$ of THF for $6 \mathrm{~h}$ and cultured with $0.5 \mathrm{mM} \mathrm{CoCl}_{2}$ for $24 \mathrm{~h}$. The level of HO- 1 was detected and normalized with the level of $\beta$-actin. (E) SH-SY5y cells $\left(1 \times 10^{5} /\right.$ well, 6 -well plate) were treated with $40 \mu \mathrm{M}$ of THF for $1 \mathrm{~h}$ and cultured with $0.5 \mathrm{mM} \mathrm{CoCl}_{2}$ for $1 \mathrm{~h}$. Nucleic extract was separated from whole lysate by using NE-PER kit. The translocation of Nrf2 was detected from nucleic extract and cytosolic extract. The mean value of three experiments \pm SEM is presented. ${ }^{*} p<0.05$ between mock-treated cells $(\mathbf{A}-\mathbf{C})$ or two cells $(\mathbf{D}, \mathbf{E})$.

\subsection{Enhancement of HO-1 by THF Pre-treatment Protects SH-SY5y Cells from $\mathrm{CoCl}_{2}$-Induced Neurotoxicity in Hypoxic Condition}

Since the expression of induced HO-1 by antioxidants has been reported to protect cells against cytotoxic conditions, including hypoxia, we investigated whether $\mathrm{HO}-1$ induction by THF treatment is involved in the protective role of THF under hypoxic conditions. To remove the cytoprotective effect of HO- 1 induced by THF pre-treatment, cells were pretreated with $20 \mu \mathrm{M}$ SnPP to inhibit the activity of HO-1, then the cell viability was assessed. Figure 8A shows that pre-treatment with SnPP significantly mitigates the protective effect of THF in SH-SY5y cells. SH-SY5y cells pre-treated with SnPP also revealed undiminished mRNA levels of hypoxia-related genes, including HIF1a, $p 53, V E G F$, and GLUT1 (Figure 8B). To confirm whether pre-treatment with SnPP removes the antioxidative effect of THF in $\mathrm{CoCl}_{2}$-induced hypoxia, generated ROS were measured in $\mathrm{SH}-\mathrm{SY} 5 \mathrm{y}$ cells pre-treated with $\mathrm{SnPP}$ and THF and exposed to $\mathrm{CoCl}_{2}$. Figure $8 \mathrm{C}$ shows that the suppressive effect of THF 
pre-treatment on ROS generation was mitigated in SH-SY5y cells. Interstingly, treatment with $20 \mu \mathrm{M}$ SnPP does not affect to cell viability, mRNA level of hypoxia-related genes and ROS production. These data demonstrated that induction of HO-1 expression by THF pre-treatment protects SH-SY5y cells from cytotoxicity induced by $\mathrm{CoCl}_{2}$ treatment.

A

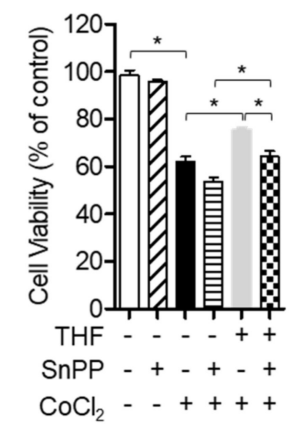

B

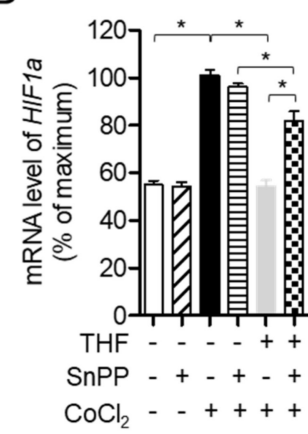

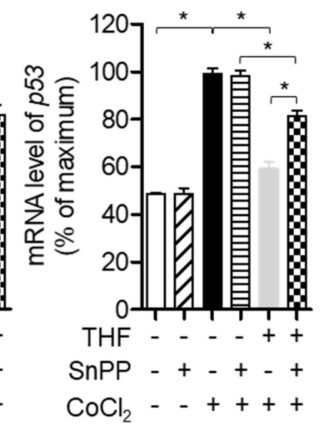

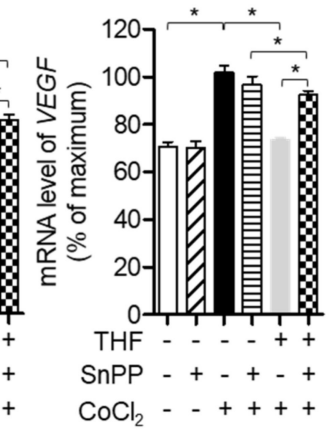

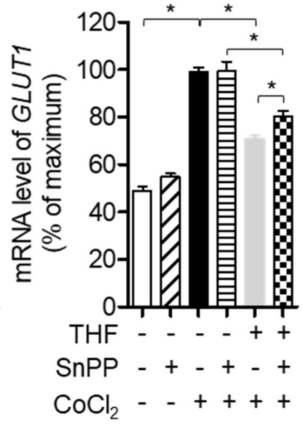

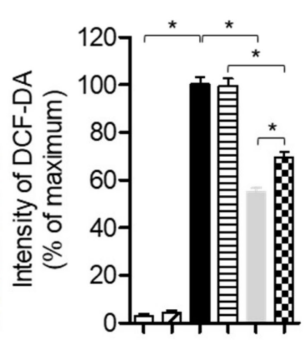

C
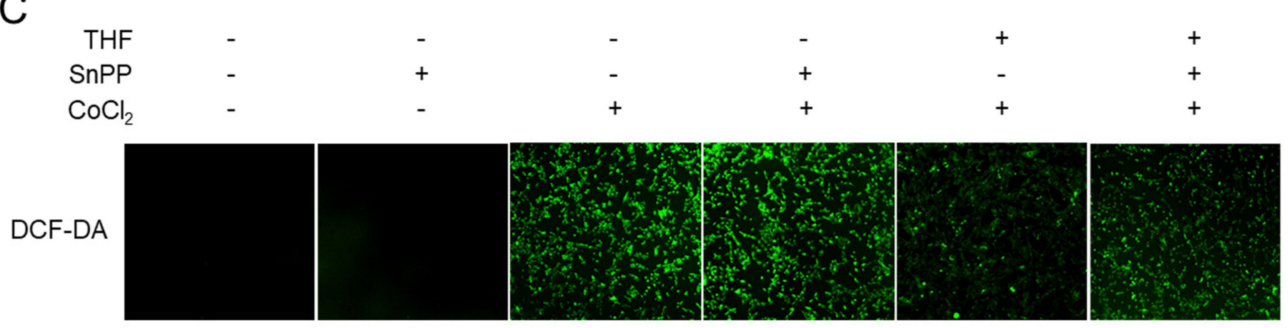

Figure 8. Enhancement of HO-1 by THF pre-treatment protects $\mathrm{SH}-\mathrm{SY} 5 \mathrm{y}$ cells from $\mathrm{CoCl}_{2}$-induced neurotoxicity in hypoxic condition. (A) SH-SY5y cells $\left(1 \times 10^{4} /\right.$ well, 96-well plate) were pre-treated with $20 \mu \mathrm{M} \mathrm{SnPP}$ for $1 \mathrm{~h}$ and then the indicated concentration $(0$ to $40 \mu \mathrm{M})$ of THF for $6 \mathrm{~h}$. After treatment with $0.5 \mathrm{mM} \mathrm{CoCl}_{2}$ for $24 \mathrm{~h}$, cell viability was assessed by MTT assay. (B) SH-SY5y cells $\left(1 \times 10^{5} /\right.$ well, 6 -well plate) were pre-treated with $20 \mu \mathrm{M} \mathrm{SnPP}$ for $1 \mathrm{~h}$ and then the indicated concentration $(0$ to $40 \mu \mathrm{M})$ of THF for $6 \mathrm{~h}$. After treatment with $0.5 \mathrm{mM} \mathrm{CoCl}_{2}$ for $6 \mathrm{~h}$, cells were harvested for the isolation of total RNA. The mRNA level of the indicated genes were measured and normalized with the level of GAPDH. (C) SH-SY5y cells $\left(1 \times 10^{4}\right.$ /well, 96-well plate) were pre-treated with $20 \mu \mathrm{M} \mathrm{SnPP}$ for $1 \mathrm{~h}$ and then the indicated concentration $(0$ to $40 \mu \mathrm{M})$ of THF for $6 \mathrm{~h}$. After treatment with $0.5 \mathrm{mM} \mathrm{CoCl}_{2}$ for $24 \mathrm{~h}$, cells were incubated with $2 \mu \mathrm{M}$ of DCF-DA for 20 min in dark. Generated ROS were detected by IncuCyte imaging system. The mean value of three experiments \pm SEM is presented. ${ }^{*} p<0.05$ between two indicated groups.

\section{Discussion}

It has been widely studied that the expression of VEGF and GLUT1 are regulated by HIF1 $\alpha$ under hypoxic conditions. The biological function of VEGF has been reported to promote angiogenesis and increase the permeability of blood vessels under hypoxic conditions [24,25]. GLUT1 is a part of glucose transporter family that is located on the cell membrane and induces glucose transport to the cells. Several previous studies have demonstrated that cells induce the expression of VEGF and GLUT1 to absorb more oxygen in situations where oxygen is limited [7-9]. In addition, it has been shown that HIF $1 \alpha$ binds to a specific sequence in target genes of hypoxia-responsive promoters, including p53, VEGF, and GLUT1, depending on the concentration of oxygen [26]. In this study, we investigated whether $\mathrm{CoCl}_{2}$-induced hypoxia induces the expression of $\mathrm{HIF} 1 \alpha$ and THF pre-treatment suppresses this increment in SH-SY5y cells (Figure 5). We also showed that THF pre-treatment reduced the expression of VEGF and GLUT1 at the mRNA and protein levels. Results from the inhibitor assay confirmed that induction of HO-1 by THF pre-treatment plays a critical role in cytoprotection under hypoxic conditions (Figure 8). These results suggest that pre-treatment with THF indirectly regulates the expression of $\mathrm{HIF} 1 \alpha$ via promotion of the $\mathrm{HO}-1 / \mathrm{Nrf} 2$ pathway rather than direct regulation in vitro. 
Further studies should include whether THF is directly involved in the transcription of HIF1a, p53, VEGF, and GLUT1 genes by performing EMSA assay.

To maintain normal cellular signaling response, ROS generation is tightly regulated in brain tissue through the expression of antioxidant enzymes, including SOD and CAT. In particular, strategies to reduce oxidative stress in brain tissue have been considered promising for the development of therapeutics for neurodegenerative diseases. One of the main factors inducing oxidative stress in the brain is the limited concentration of oxygen that causes a hypoxic environment. Excessive ROS generated in hypoxic conditions leads to apoptosis, DNA damages, and cell death. We confirmed whether exposure to $\mathrm{CoCl}_{2}$ augments ROS generation in SH-SY5y cells, but THF pre-treatment effectively suppresses generated ROS (Figure 6A). In addition, the expression of SOD and CAT was significantly upregulated in a THF dose-dependent manner (Figure 6B,C). Figure 8C confirmed that HO-1 induced by THF pre-treatment is highly involved in the regulatory role of THF in the generation of ROS under hypoxic conditions. These data suggest that promotion of HO-1 expression by THF pre-treatment effectively protects neuronal cells from neurotoxicity induced by hypoxic condition.

Anti-apoptotic or cytoprotective effects of flavonoids have been widely elucidated. Quercetin, the most studied flavonoid, has been investigated that it partially blocks $\mathrm{H}_{2} \mathrm{O}_{2}$ induced apoptosis through the regulation of activator protein 1 (AP-1) transcription factor [27]. In particular, flavanone compounds have been studied as anti-apoptotic activity. Treatment with hesperetin and its metabolites, 5-nitro-hesperetin has shown a protective effect on neuronal cell death by modulation of ERK/PI3K pathway and naringenin possesses an anti-apoptotic activity in ischaemic stroke damage via Nrf2/HO-1 signaling pathway $[28,29]$. In the present study, we explored the anti-apoptotic effect of THF, one of flavanone compounds, in $\mathrm{CoCl}_{2}$-induced hypoxia condition through induction of Nrf2/HO-1 cytoprotective pathway. Our study suggests that a flavanone family including naringenin, hesperetin and THF has a potential to be developed as a source of therapeutic for neurodegenerative diseases.

\section{Conclusions}

In this study, we evaluated the cytoprotective effect of THF on $\mathrm{CoCl}_{2}$-induced neurotoxicity by promoting the HO-1/Nrf2 pathway. We showed that THF pre-treatment effectively enhanced the expression of HO-1 through the Nrf2 pathway in SH-SY5y cells and induced HO-1 suppresses the expression of hypoxia-related genes induced by $\mathrm{CoCl}_{2}$ treatment. This reduced hypoxic condition by THF pre-treatment mitigates oxidative stress and leads to protection of SH-SY5y cells from neurotoxicity by $\mathrm{CoCl}_{2}$ treatment.

Author Contributions: H.-S.L. performed the experiments and wrote the manuscript, performed the statistical analysis. G.-S.J. participated in study design and coordination as well as drafting the manuscript. All authors have read and agreed to the published version of the manuscript.

Funding: This research received no external funding.

Institutional Review Board Statement: Not applicable.

Informed Consent Statement: Not applicable.

Data Availability Statement: The data presented in this study are available on request from the corresponding author.

Conflicts of Interest: The authors declare no conflict of interest.

\section{References}

1. Martini, S.; Austin, T.; Aceti, A.; Faldella, G.; Corvaglia, L. Free radicals and neonatal encephalopathy: Mechanisms of injury, biomarkers, and antioxidant treatment perspectives. Pediatr. Res. 2020, 87, 823-833. [CrossRef] [PubMed]

2. Ratan, R.R.; Siddiq, A.; Smirnova, N.; Karpisheva, K.; Haskew-Layton, R.; McConoughey, S.; Langley, B.; Estevez, A.; Huerta, P.T.; Volpe, B.; et al. Harnessing hypoxic adaptation to prevent, treat, and repair stroke. J. Mol. Med. 2007, 85, 1331-1338. [CrossRef]

3. Yagishita, S.; Hirasawa, A. Intermittent hypoxia produces Alzheimer disease? Oncotarget 2017, 8, 41786-41787. [CrossRef] 
4. Snyder, B.; Shell, B.; Cunningham, J.T.; Cunningham, R.L. Chronic intermittent hypoxia induces oxidative stress and inflammation in brain regions associated with early-stage neurodegeneration. Physiol. Rep. 2017, 5. [CrossRef]

5. Wiener, C.M.; Booth, G.; Semenza, G.L. In vivo expression of mRNAs encoding hypoxia-inducible factor 1. Biochem. Biophys. Res. Commun. 1996, 225, 485-488. [CrossRef]

6. Jin, K.L.; Mao, X.O.; Nagayama, T.; Goldsmith, P.C.; Greenberg, D.A. Induction of vascular endothelial growth factor and hypoxia-inducible factor- $1 \alpha$ by global ischemia in rat brain. Neuroscience 2000, 99, 577-585. [CrossRef]

7. Koumenis, C.; Alarcon, R.; Hammond, E.; Sutphin, P.; Hoffman, W.; Murphy, M.; Derr, J.; Taya, Y.; Lowe, S.W.; Kastan, M.; et al. Regulation of p53 by Hypoxia: Dissociation of Transcriptional Repression and Apoptosis from p53-Dependent Transactivation. Mol. Cell. Biol. 2001, 21, 1297-1310. [CrossRef]

8. Krock, B.L.; Skuli, N.; Simon, M.C. Hypoxia-Induced Angiogenesis: Good and Evil. Genes Cancer 2011, 2, 1117-1133. [CrossRef]

9. Hayashi, M.; Sakata, M.; Takeda, T.; Yamamoto, T.; Okamoto, Y.; Sawada, K.; Kimura, A.; Minekawa, R.; Tahara, M.; Tasaka, K.; et al. Induction of glucose transporter 1 expression through hypoxia-inducible factor $1 \alpha$ under hypoxic conditions in trophoblast-derived cells. J. Endocrinol. 2004, 183, 145-154. [CrossRef] [PubMed]

10. Ndisang, J.F. Synergistic Interaction Between Heme Oxygenase (HO) and Nuclear-Factor E2- Related Factor-2 (Nrf2) against Oxidative Stress in Cardiovascular Related Diseases. Curr. Pharm. Des. 2017, 23, 1465-1470. [CrossRef] [PubMed]

11. Lee, D.H.; Park, J.S.; Lee, Y.S.; Sung, S.H.; Lee, Y.H.; Bae, S.H. The hypertension drug, verapamil, activates Nrf2 by promoting p62-dependent autophagic Keap1 degradation and prevents acetaminophen-induced cytotoxicity. BMB Rep. 2017, 50, 91-96. [CrossRef] [PubMed]

12. Yang, B.; Cheng, H.; Wang, L.; Fu, J.; Zhang, G.; Guan, D.; Qi, R.; Gao, X.; Zhao, R. Protective roles of NRF2 signaling pathway in cobalt chloride-induced hypoxic cytotoxicity in human HaCaT keratinocytes. Toxicol. Appl. Pharmacol. 2018, 355, $189-197$. [CrossRef]

13. Wang, W.; Weng, X.; Cheng, D. Antioxidant activities of natural phenolic components from Dalbergia odorifera T. Chen. Food Chem. 2000, 71, 45-49. [CrossRef]

14. Lee, D.S.; Kim, K.S.; Ko, W.; Li, B.; Keo, S.; Jeong, G.S.; Oh, H.; Kim, Y.C. The neoflavonoid latifolin isolated from meoh extract of Dalbergia odorifera attenuates inflammatory responses by inhibiting NF- $\mathrm{kB}$ activation via Nrf2-mediated heme oxygenase-1 expression. Phyther. Res. 2014, 28, 1216-1223. [CrossRef] [PubMed]

15. Kim, E.N.; Kim, Y.G.; Lee, J.H.; Min, B.S.; Jeong, G.S. 6,7,4'-Trihydroxyflavone inhibits osteoclast formation and bone resorption in vitro and in vivo. Phyther. Res. 2019, 33, 2948-2959. [CrossRef]

16. Lee, H.S.; Jeong, G.S. 6,7,4' -Trihydroxyflavanone Prevents Methamphetamine-Induced T Cell Deactivation by Protecting the Activated T Cells from Apoptosis. Am. J. Chin. Med. 2021. [CrossRef] [PubMed]

17. Cavia-Saiz, M.; Busto, M.D.; Pilar-Izquierdo, M.C.; Ortega, N.; Perez-Mateos, M.; Muñiz, P. Antioxidant properties, radical scavenging activity and biomolecule protection capacity of flavonoid naringenin and its glycoside naringin: A comparative study. J. Sci. Food Agric. 2010, 90, 1238-1244. [CrossRef] [PubMed]

18. Rashmi, R.; Bojan Magesh, S.; Mohanram Ramkumar, K.; Suryanarayanan, S.; Venkata SubbaRao, M. Antioxidant Potential of Naringenin Helps to Protect Liver Tissue from Streptozotocin-Induced Damage. Rep. Biochem. Mol. Biol. 2018, 7, 76-84. [PubMed]

19. Shen, C.C.; Cheng, J.J.; Lay, H.L.; Wu, S.Y.; Ni, C.L.; Teng, C.M.; Chen, C.C. Cytotoxic apigenin derivatives from Chrysopogon aciculatis. J. Nat. Prod. 2012, 75, 198-201. [CrossRef] [PubMed]

20. Li, K.; Li, W.; Yin, H.; Cheong, Y.K.; Ren, G.; Yang, Z. Pretreatment-Etidronate Alleviates CoCl 2 Induced-SH-SY5Y Cell Apoptosis via Decreased HIF-1 $\alpha$ and TRPC5 Channel Proteins. Neurochem. Res. 2019, 44, 428-440. [CrossRef]

21. Kurokawa, M.; Kornbluth, S. Caspases and kinases in a death grip. Cell 2009, 138, 838-854. [CrossRef] [PubMed]

22. McGarry, T.; Biniecka, M.; Veale, D.J.; Fearon, U. Hypoxia, oxidative stress and inflammation. Free Radic. Biol. Med. 2018, 125, 15-24. [CrossRef] [PubMed]

23. Zhou, H.; Lu, F.; Latham, C.; Zander, D.S.; Visner, G.A. Heme oxygenase-1 expression in human lungs with cystic fibrosis and cytoprotective effects against Pseudomonas aeruginosa in vitro. Am. J. Respir. Crit. Care Med. 2004, 170, 633-640. [CrossRef]

24. Yuan, F.; Chen, Y.; Dellian, M.; Safabakhsh, N.; Ferrara, N.; Jain, R.K. Time-dependent vascular regression and permeability changes in established human tumor xenografts induced by an anti-vascular endothelial growth factor/vascular permeability factor antibody. Proc. Natl. Acad. Sci. USA 1996, 93, 14765-14770. [CrossRef] [PubMed]

25. Plate, K.H.; Breier, G.; Weich, H.A.; Risau, W. Vascular endothelial growth factor is a potential tumour angiogenesis factor in human gliomas in vivo. Nature 1992, 359, 845-848. [CrossRef]

26. Iyer, N.V.; Kotch, L.E.; Agani, F.; Leung, S.W.; Laughner, E.; Wenger, R.H.; Gassmann, M.; Gearhart, J.D.; Lawler, A.M.; Yu, A.Y.; et al. Cellular and developmental control of O2 homeostasis by hypoxia- inducible factor $1 \alpha$. Genes Dev. 1998, 12, 149-162. [CrossRef]

27. Ishikawa, Y.; Kitamura, M. Anti-apoptotic effect of quercetin: Intervention in the JNK- and ERK-mediated apoptotic pathways. Kidney Int. 2000, 58, 1078-1087. [CrossRef] [PubMed]

28. Vauzour, D.; Vafeiadou, K.; Rice-Evans, C.; Williams, R.J.; Spencer, J.P.E. Activation of pro-survival Akt and ERK1/2 signalling pathways underlie the anti-apoptotic effects of flavanones in cortical neurons. J. Neurochem. 2007, 103, 1355-1367. [CrossRef]

29. Wang, K.; Chen, Z.; Huang, J.; Huang, L.; Luo, N.; Liang, X.; Liang, M.; Xie, W. Naringenin prevents ischaemic stroke damage via anti-apoptotic and anti-oxidant effects. Clin. Exp. Pharmacol. Physiol. 2017, 44, 862-871. [CrossRef] 